\title{
Endotoxin Contamination
}

National Cancer Institute

\section{Source}

National Cancer Institute. Endotoxin Contamination. NCI Thesaurus. Code C92049.

The undesirable presence of toxins associated with certain bacteria (e.g. gram negative bacteria). 